\title{
Management of Bone Bleeding During Surgery and Its Impact on the Incidence of Post-Operative Osteomyelitis
}

\author{
Tadeusz Wellisz \\ University of Southern California
}

USA

\section{Introduction}

\subsection{Synopsis}

A wide range of orthopedic, cardiothoracic, neurological, and maxillofacial procedures requires that the bone be cut or resected, either to operate on the osseous tissue itself or to gain access to other organs. As any living tissue, bone bleeds when cut or fractured, and to reduce the risk of post-operative complications, bone bleeding needs to be managed during surgery. The present chapter examines the relationship between the management of bleeding and post-operative complications, and, in particular, the impact of bone hemostasis materials on the incidence of post-operative infection of soft tissue and osteomyelitis. Section 2, "Bone Surgery and Management of Bleeding," opens the argument by discussing the increase in the number of procedures involving the bone, the importance of effective bone and soft tissue hemostasis for assuring positive surgical outcome, and the surgeons' reliance on bone wax composed of beeswax, despite serious complications associated with its use. Section 3, "Surgical Site Infections and Osteomyelitis," focuses on the growing incidents of surgical site infections and postoperative osteomyelitis, and the added risk posed by the presence of antibiotic-resistant bacteria. Section 4, "Antibiotic Prophylaxis," discusses systemic SSI prevention and the use and effectiveness of topical antibiotic prophylaxis. "Systemic and Perioperative Risk Factors for Postoperative Osteomyelitis," in Section 5 analyses infection risk factors and predictors of complications following cardiac, orthopedic, and neurosurgical procedures. It focuses on excessive bleeding and subsequent extended duration of surgical procedure as infection risk factors, and the importance of effective bone hemostasis in minimizing the risk. Section 6, "Bone Wax as a Modifiable Risk Factor for Osteomyelitis, Chronic Inflammation, and Inhibited Bone Healing," discusses a body of research linking the use of traditional bone wax, most widely used bone hemostasis material, to inhibition of bone healing, inflammation, and increased soft tissue infection and osteomyelitis rates. The use of bone wax - and the choice of bone hemostasis material in general - remains a largely overlooked modifiable risk factor for osteomyelitis and other post-operative infections. Surgeons are often unaware of the post-operative complications attributed to the use of bone wax and unfamiliar with the range of alternatives available for bone hemostasis. Section 7, "Alternative Bone Hemostasis Materials and Methods," elaborates on a wide 
range of existing alternatives to bone wax, including synthetic topical bone hemostats which replicate the handling of traditional bone wax without its risks. The section also reviews studies of topical bone hemostasis materials and offers an analysis of existing comparative studies of new bone formation and healing, rate of infection, osteomyelitis, and the materials' effectiveness as bone hemostats, underscoring the role the surgeons' choice of bone hemostasis material can play in the promotion and prevention of postoperative complications. Polymer bone hemostats emerge in the studies as materials that do not inhibit bone healing and do not promote osteomyelitis or inflammation. "Redefining the Management of Bone Bleeding: Osteomyelitis, Bone Healing, and Topical Therapeutics" is the focus of Section 8, which explores the potential of combining topical bone hemostasis materials with therapeutics -- antibiotics or bone grafts - a combination which would make the management of bone bleeding an aspect of a larger surgical procedure and an important step in prevention and treatment of osteomyelitis. Section 9 concludes that a better understanding by the surgeons of the adverse effects of bone wax and of the overall impact bone hemostasis technique and material choice have on the clinical outcome may help reduce infections and the rate of osteomyelitis as well as broaden the repertoire of medical tools available to operating physicians and improve outcomes across surgical procedures.

\subsection{Key terms}

Osteomyelitis; post-operative infection; bone wax; modifiable risk factor for infection; topical bone hemostasis; topical therapeutics; alternatives to bone wax; bone surgery.

\section{Bone surgery and management of bleeding}

\subsection{Bone bleeding in surgery}

Bone, whether sternal, spinal, or any other, is a living tissue, and any invasive procedure involving the cutting of the bone requires management of bone bleeding, both to reduce blood loss and hematoma formation for the patient and to ensure good visibility of the operating site for the surgeon. To optimize surgical success and patient outcome, it is important to maintain a fine balance between bleeding and clotting during surgery, so that blood continues to flow to the tissues at the surgical site, but its loss is not excessive (Samudrala, 2008). ${ }^{1}$ Uncontrolled continuous bleeding can obscure the surgical field, prolong operating time, increase the risk of physiologic complications, and expose the patient to additional problems associated with blood transfusion. For patients undergoing elective coronary artery bypass graft surgery, allogeneic blood transfusion has been shown to double the risk of infection (Rogers et al., 2009). ${ }^{2}$

\footnotetext{
${ }^{1}$ Samudrala, S. “Topical Hemostatic Agents in Surgery: A Surgeon's Perspective." AORN Journal, 2008. Supplement: Intraoperative Bleeding and Hemostasis in Surgical Procedures. vol. 88, no 3: p. S2-11

${ }^{2}$ In a cohort study of 24,789 Medicare beneficiaries who received coronary artery bypass graft surgery, allogeneic blood transfusion increased the odds of in-hospital infection 2.0-fold, in-hospital mortality 4.7-fold, 30-day readmission 1.4-fold, and 30-day mortality 2.9-fold. See: Mary AM Rogers, Neil Blumberg, Sanjay Saint, Kenneth M Langa' and Brahmajee K Nallamothu. "Hospital variation in transfusion and infection after cardiac surgery: a cohort study." BMC Medicine 2009, 7:37doi:10.1186/1741-7015-7-37
} 


\subsection{Growing number of surgeries involving the osseous tissue}

Bone tissue is one of the most frequently transplanted tissues, second only to blood (Giannoudis, 2005). ${ }^{3}$ It is increasingly needed across surgical fields as bone grafts are used to fill defects caused by trauma, infection of soft tissue and osteomyelitis, tumor resection, reconstruction of congenital malformations, and age-related decrease of bone mass. Over 1.8 million bone graft procedures were reported in 2006, a number that has risen exponentially since 1990 and that continues to grow with the ageing of population (Hladki, 2006). ${ }^{4}$

Other surgical procedures performed on the bone have also been on the rise in the United States. The number of joint arthroplasties currently exceeds 1,000,000 procedures per year (AAOS). ${ }^{5}$ According to Centers for Disease Control and Prevention, there were 2,476,000 orthopedic and spinal surgeries in 2007, the last year for which data are available. Spine fusions and excisions of intervertebral discs accounted for 659,000 in-patient operations on the skeletal system while median sternotomies were performed 1,022,000 times in the same period in order to gain access to the heart in angioplasty and coronary artery bypass graft procedures (CDC) ${ }^{6}$

\subsection{Management of bleeding and successful surgical outcome}

During a surgical procedure involving bone, surgical technique and the management of bone bleeding are important factors in determining a successful outcome. When bone is cut, irrigation is used to prevent heat formation and thermal injury to the bone. Cut surfaces are kept moist to avoid desiccation, and efforts are made to preserve the blood supply. The blood flow through cortical bone occurs through the relatively small vascular channels of the Haversian system. Bone bleeding originates predominantly in the cancellous bone. The hematopoietic elements are contained within a honeycombed network of vascular channels and can be a source of profuse bleeding. Electrocautery, which is useful in soft tissue hemostasis, functions primarily to collapse and seal blood vessels. To be effective in controlling bone bleeding, it would have to generate sufficient heat to create a coagulum that would physically block vascular channels - the thermal injury to the adjacent bone would be of such magnitude, that any hemostatic benefit would be offset by the resultant bone necrosis.

\subsection{Effective bone hemostasis}

The most immediate and effective way to stem bone bleeding is to physically block the open vascular channels, a process known as tamponade. Until the recent introduction of soluble

${ }^{3}$ Giannoudis, P.V., H. Dinopoulos, and E. Tsiridis, "Bone substitutes: an update." Injury, 2005. 36 Suppl 3: p. S20-7

${ }^{4}$ Hladki, W., L. Brongel, and J. Lorkowski, "Injuries in the elderly patients." Przeglad Lekarski, 2006. 63 Suppl 5: p. 1-4.0

${ }^{5}$ AAOS Medical Letter: “Antibiotic Prophylaxis for Bacteremia in Patients with Joint Replacements." February 2009, Revised June 2010. http://www.aaos.org/about/papers/advistmt/1033.asp

${ }^{6}$ Source: National Hospital Discharge Survey: 2007 Summary, table 8. Centers for Disease Control and Prevention http://www.cdc.gov/nchs/fastats/insurg.htm accessed July 31, 2011. 
synthetic polymers, the only widely available tamponade material was bone wax, a beeswax based blend. Bone wax sticks to bone blocking the vascular channels, providing immediate bone hemostasis. Although inexpensive and easy to use, bone wax has a number of troublesome side effects. Once applied to bone, bone wax remains at the site indefinitely. Bone wax is known to interfere with bone healing, elicit chronic inflammatory reactions, and increase infection rates (Allison, 1994; Armstrong et al., 2010; Chun, 1988; Finn, 1992; Johnson, 1981; Nelson, 1990; Gibbs, 2004; Sawan et al., 2010; Schonauer et al. 2004; Solheim et al., 1992; Wellisz et al., 2006, 2008a, 2008b). ${ }^{7}$ And yet, the use of bone wax remains relatively widespread, and surgeons are often unaware of the complications surrounding its application. In fact, the effect of bone hemostasis materials in general, not just bone wax, on post-operative infection remains largely neglected in the current professional literature. By and large, existing infection studies in orthopedic, cardiac, and neurological surgery do not mention the type of bone hemostasis materials used in any given trial, overlooking the fact that bone hemostasis materials are in themselves modifiable risk factors, both for soft tissue infection and for osteomyelitis.

\section{Surgical site infections and osteomyelitis}

\subsection{Risk of surgical site infection}

Surgical site infections (SSI) account for nearly $25 \%$ of all hospital infections in the United States. All tissues, soft and osseous, are susceptible to post-operative complications; an increasing number of infections are methicillin-resistant, making treatment more difficult and effective prophylaxis more urgent (Georgia Epidemiology Report, 2004; Kronemyer, 2004; Styers et al, 2006). ${ }^{8}$ Although technological advances and focus on prevention lower

\footnotetext{
${ }^{7}$ For detailed discussions of various complications related to the use of bone wax, see: Allison RT. "Foreign body reactions and an associated histological artifact due to bonewax." Br. J. Biomed. Sci. 1994; 51:14-17. Armstrong et al. BMC Surgery 2010, 10:37 http:/ / www.biomedcentral.com/1471-2482/10/37; Chun PKC, Virmani R, Mason TE, Johnson F. “Bone wax granuloma causing saphenous vein thrombosis.” Am. Heart J. 1988; 115:1310-1313. Finn MD, Schow SR, Scneiderman ED. "Osseous regeneration in the presence of four common hemostatic agents." J. Oral Maxillofac. Surg. 1992;50:608-612. Gibbs L, Kakis A, Weinstein P, Conte J. "Bone wax as a risk factor for surgical site infection following neurospinal surgery." Infect. Control Hosp. Epidemiol. 2004; 25:346-348. Johnson P, Fromm D. "Effects of bone wax on bacterial clearance." Surgery 1981; 89:206-209. Nelson DR, Buxton TB, Luu QN, Rissing JP. "The promotional effect of bone wax on experimental Staphylococcus Aureus osteomyelitis." J. Thorac. Cardiovasc. Surg. 1990; 99:977-980. Sawan A, Elhawary Y, Zaghlool Amer M, \& Abdel Rahman M. "Controversial Role of Two Different Local Haemostatic Agents on Bone Healing." Journal of American Science, 2010; 6(12):155-163]. (ISSN: 1545-1003); Schonauer, C., E. Tessitore, et al. (2004). "The use of local agents: bone wax, gelatin, collagen, oxidized cellulose." Eur Spine J 13 Suppl 1: S89-96. Solheim E, Pinholt EM, Bang G, Sudmann E. "Effect of local hemostatics on bone induction in rats: a comparative study of bone wax, fibrin-collagen paste, and bioerodible polyorthoester with and without gentamicin." J Biomed Mater Res. 1992 Jun;26(6):791-800. Wellisz T, Armstrong JK, Cambridge J, Fisher TC: "Ostene, a new water-soluble bone hemostasis agent." J Craniofac Surg 17: 420-425, 2006. Wellisz T, An YH, Wen X, Kang Q, Hill CM, Armstrong JK. "Infection rates and healing using bone wax and a soluble polymer material." Clin Orthop Relat Res 2008; 466:481-6. Wellisz T, Armstrong JK, Cambridge J, et al. "The effects of a soluble polymer and bone wax on sternal healing in an animal model." Ann Thorac Surg 2008; 85:1776-80;

8 Georgia Epidemiology Report (GER). Community-associated Methicillin Resistant Staphylococcus aureus (MRSA). June 2004;20:1-4. Kronemyer B. MRSA incidence on the rise. Infectious Disease News. May 1, 2004. http://www.infectiousdiseasenews.com/article/33489.aspx. Accessed August 5, 2011; Styers D,
} 
the risk of post-operative infection, when the complication does occur, the human and financial cost is extremely high. Patients who develop surgical site infections (SSI) are 60\% more likely to spend time in an intensive care unit; they are five times more likely to be readmitted to the hospital; they have three times the length of hospital stay; and their mortality rate is five times that of inpatients without wound infections (CDC, 2011; Noskin et al., 2005). ${ }^{9}$ Infections caused by resistant organisms exact an even higher toll on individual patients and healthcare system (Carmeli et al., 1999; Cosgrove et al., 2002; Kronemyer, 2004). ${ }^{10}$

\subsection{Risk of bone infection in cardiac, orthopedic, and neurological surgery}

In cardiac surgery, infections of median sternotomy wounds are a rare but grave complication. Mediastinitis occurs in $0.3-5 \%$ of cases, but it is associated with a mortality rate between 14 and $47 \%$ (Losanoff et al., 2002). ${ }^{11}$ Left untreated, these infections can extend to aortic and cardiac suture lines, prosthetic grafts, and intracardiac prostheses (Pairolero \& Arnold, 1986). ${ }^{12}$ The added financial cost of treating mediastinitis to an individual institution has been reported as high as $\$ 500,000$ USD (Lee et. al, 2009). ${ }^{13}$ In orthopedic surgery, approximately $7 \%$ of total joint arthroplasties performed annually in the US are revision procedures - the result of deep infections of total joint replacements and the consequent failure of the initial operations (CDC; AAOS, 2010). In neurosurgery, postoperative wound infection following intracranial surgery has a reported incidence ranging from $1 \%$ to $8 \%$, with significant geographic variations in Europe and North America, and it carries a high risk of morbidity and mortality if not aggressively treated. ${ }^{14}$

\section{Antibiotic prophylaxis}

\subsection{SSI Prevention}

While treatment of Surgical Site Infections (SSI) is essential, the focus in the medical community remains on preventing the complications from occurring. There is much clinical

Sheehan DJ, Hogan P, et al. "Laboratory-based surveillance of current antimicrobial resistance patterns and trends among Staphylococcus aureus: 2005 status in the United States." Ann Clin Microbiol Antimicrob. 2006. 5:2

9 Sources: Centers for Disease Control and Prevention (CDC). National Center for Health Statistics. Leading causes of Death. http://www.cdc.gov/nchs/fastats/lcod.htm. Accessed July 30, 2011; for complications and associated cost of infections, see: Gary A Noskin, Robert J. Rubin, et al. "The Burden of Staphylococcus aureus Infections on Hospitals in the United States." Arch Intern. Med. 2005;165:17561761.

10 See for example: Carmeli Y, Troillet N, Karchmer AW, et al. "Health and economic outcomes of antibiotic resistance in Pseudomonas aeruginosa." Arch Intern Med. 1999;159:1127-1132; Cosgrove SE et al. "Health and economic outcomes of the emergence of third-generation cephalosporin resistance in Enterobacter species." Arch Intern Med. 2002. 162:185-190; Kronemyer, 2004

${ }_{11}$ Julian E. Losanoff, Bruce W. Richman, James W. Jones. "Disruption and infection of median sternotomy: a comprehensive review." Eur J Cardiothorac Surg 2002;21:831-839

12 Pairolero PC \& Arnold PG "Management of Infected Median Sternotomy Wounds." Ann Thorac Surg, 1986; 42:1-2. DOI: 10.1016/S0003-4975(10)61822-X

${ }^{13}$ Lee JC, Raman J, Song DH. "Primary sternal closure with titanium plate fixation: plastic surgery effecting a paradigm shift." Plast Reconstr Surg 2010;125:1720-4.

${ }_{14}$ McClelland, S., "Postoperative intracranial neurosurgery infection rates in North America versus Europe: A systematic analysis." Am J Infect Control 2008; 36:570-3 
evidence that antibiotics used preventively significantly reduce the occurrence of SSI across surgical fields. As a result, antimicrobial prophylaxis is becoming the standard of care. The American Academy of Orthopedic Surgeons (AAOS), the American Academy of Neurosurgeons (AANS), The Society of Thoracic Surgeons (STS), and the North American Spine Society (NASS) currently recommend perioperative use of antibiotics to lower the risk of infection of soft tissue and the incidence of post-operative osteomyelitis in spinal procedures, neurosurgery, orthopedic and cardiac surgery. There is a growing consensus that patients in high-risk groups, those undergoing procedures associated with high infection rates, involving implantation of grafts or prosthetic material, or surgeries in which the consequences of infection are serious, should receive systemic perioperative antibiotics targeting the most likely organisms (AAOS, 2010; Edwards et al., 2006; Engelman et al., 2007; Watters et al., 2007). ${ }^{15}$

\subsection{Systemic antibiotic prophylaxis}

The value of systemic prophylaxis depends critically upon the activity of the antibiotic towards the causative organisms. In cardiac procedures, peri-operative intravenous antibiotic prophylaxis was shown to reduce the incidence of SWIs by up to $80 \%$ compared to placebo (Kreter \& Woods, 1992). ${ }^{16}$ In neurosurgical and orthopedic procedures, wound infection rates decreased by $63 \%$ with IV antibiotic prophylaxis. But IV prophylaxis tends to target infections caused by gram-negative bacteria, and while S. aureus and S. epidermidis are the most common causes of SSI, they are increasingly methicillin resistant (CDC, 2009).17 Vancomycin is often the only effective antibiotic available for treatment of surgical site infection caused by methicillin-resistant gram-positive organisms. Since broad systemic use of Vancomycin for prophylaxis is discouraged for epidemiological reasons, local delivery of antibiotic directly to the surgical site may be an alternative or an effective adjunct to systemic SSI prophylaxis.

\subsection{Use of topical antibiotic prophylaxis in surgery}

While systemic use of antibiotic prophylaxis is generally recommended and practiced, there is evidence that local application directly to the the surgical site is effective at reducing the incidence of post-operative infection of both soft tissue and osteomyelitis in cardiac, spinal, orthopedic and neuro-surgical procedures. Topical application of Vancomycin powder to the sternal edges has been shown to reduce SWI following cardiac surgery (Vander et al.,

\footnotetext{
15 For detailed practice guidelines, see: Edwards et al. "The STS Practice Guideline Series: Antibiotic Prophylaxis in Cardiac Surgery, Part I: Duration." Annals of Thoracic Surgery 81(1): 397-404 (2006); Engelman R et al. "The STS Practice Guideline Series: Antibiotic Prophylaxis in Cardiac Surgery, Part II: Antibiotic Choice." Annals of Thoracic Surgery 2007; 83: 1569-1576; Watters WC III, MD et al. North American Spine Society Evidence-Based Clinical Guidelines for Multidisciplinary Spine Care, 2007. AAOS Information Statement "Antibiotic Prophylaxis for Bacteremia in Patients with Joint Replacements." February 2009, revised June 2010. http://www.aaos.org/about/papers/advistmt/ 1033.asp retrieved July 30, 2011;

16 Kreter B, Woods M. "Antibiotic prophylaxis for cardiothoracic operations. Meta-analysis of thirty years of clinical trials." J Thorac Cardiovasc Surg 1992;104(3):590-9

17 Centers for Disease Control and Prevention (CDC). Prevent antimicrobial resistance in healthcare settings. http://www.cdc.gov/drugresistance/healthcare/problem.htm. Accessed September 27, 2009.
} 
1989). ${ }^{18}$ There is also anecdotal evidence that cardiothoracic surgeons in the United States commonly consider topical application of Vancomycin to be effective in preventing infection with resistant gram-positive organisms, and that its use is quite widespread.

\subsubsection{Effectiveness of topical antibiotic prophylaxis in spinal and cardiac procedures}

In one clinical study that highlighted the potential of local antibiotic prophylaxis, Rohde and colleagues reported and analyzed the incidence of spondylodiscitis after lumbar disc surgery in 1642 patients in a German center (Rohde et al., 1999). ${ }^{19}$ Postoperative spondylodiscitis is the result of intraoperative contamination and, theoretically, could be prevented with prophylactic antibiotics. The infection is considered rare, but the retrospective design of most existing studies and the scarce use of magnetic resonance imaging for early radiologic diagnosis suggest that the reported incidence rates may be underestimates. Of the 1642 patients, 508 were not given any prophylactic antibiotics, while in 1134 patients a collagenous sponge containing gentamicin was placed in the cleared disc space. In 19 of the 508 patients who were not treated with antibiotic prophylaxis $(3.7 \%)$, a postoperative spondylodiscitis developed, whereas none of the 1134 patients who received antibiotic prophylaxis became symptomatic, demonstrating that antibiotic-containing sponges placed in the cleared disc space were effective in completely preventing postoperative spondylodiscitis.

Local antibiotic prophylaxis of sternal wound infection was studied in a group of nearly 2000 patients from two cardiothoracic centers in Sweden (Friberg et al., 2005). ${ }^{20}$ The control group of 967 patients received routine systemic antibiotic prophylaxis with i.v. isoxazolyl-penicillin. The treatment group of 983, in addition to the same routine intravenous antibiotic prophylaxis, was also treated with a collagen sponge containing $260 \mathrm{mg}$ of Gentamicin, which was placed between the sternal halves before closure. The study end-point was any SWI identified at any time over the two-months postoperative follow-up. In total, 129 patients developed a SWI; 42 $(4.3 \%)$ in the treatment group and more than double -- 87 or $9.0 \%$-- in the control group. In a similar study, 272 patients received a Gentamicin-collagen implant under the sternum before closure and 270 served as controls (Eklund et al., 2005). ${ }^{21}$ The incidence of SWI in the control group (5.9\%) was 50\% higher than in the treatment group (4.0\%).

\subsubsection{Infection rate-reducing potential of local antibiotic prophylaxis in cardiac, orthopaedic, and neurological surgery}

Because there are relatively few local antibiotic prophylaxis studies, but the results of existing trials are consistently promising, the current North American Spine Society

\footnotetext{
18 Vander Salm TJ, Okike ON, Pasque MK, Pezzella AT, Lew R, Traina V, Mathieu R. "Reduction of sternal infection by application of topical vancomycin." J Thorac Cardiovasc Surg 1989;98(4):618-22

${ }^{19}$ Rohde et al., "Spondylodiscitis after lumbar discectomy. Incidence and a proposal for prophylaxis." Spine (Phila Pa 1976), 1998 Mar 1;23 (5):615-20.

${ }^{20}$ Friberg O, Svedjeholm R, Soderquist B, Granfeldt H, Vikerfors T, Kallman J. "Local gentamicin reduces sternal wound infections after cardiac surgery: a randomized controlled trial." Ann Thorac Surg. 2005;79(1):153-61

${ }^{21}$ Eklund, A.M., M. Valtonen, K.A. "Prophylaxis of sternal wound infections with gentamicincollagen implant: randomized controlled study in cardiac surgery." Journal of Hospital Infection (2005) $59,108-112$.
} 
Guideline, American Academy of Orthopedic Surgeons Recommendations, and Society of Thoracic Surgeons Practice Guidelines suggest further research that would lead to a more thorough and conclusive assessment of the effectiveness of local antibiotic prophylaxis (Watters et al., 2007; AAOS 2010, Edwards et al., 2006; Endelman et al., 2007).

\section{Systemic and perioperative risk factors for postoperative osteomyelitis}

\subsection{Infection risk factors in cardiac surgery}

Many systemic factors beyond the surgeon's control increase the patients' risk for soft tissue infection and osteomyelitis. In cardiac surgery, although surgeons vary in their operative treatment of complicated median sternotomy wounds (El Oakley, 1996), there is a considerable consensus, supported by multiple prospective clinical studies, that obesity stands out as one of the main predictors of poststernotomy wound complications and osteomyelitis of the sternum (Milano et al., 1995; ${ }^{22}$; Lamm et al., 1998;23 Losanoff et al., 2002; Szerafin et al., 1999). Szerafin and colleagues note the need to adjust the dose of antibiotic prophylaxis to the body weight to ensure effectiveness of this infection-preventing measure in obese patients (Szerafin et al., 1999). The incidence of infection of soft or osseous tissue in itself increases risk to patient, regardless of the patient's preoperative condition. Underscoring the importance of effective prophylaxis, Milano and colleagues found that postoperative interval mortality during the first 90 days after surgery for the patients with mediastinitis was double that of the patients without mediastinitis (11.8\% compared with 5.5\%); between 1 and 2 years after surgery interval mortality in the mediastinitis group was nearly four times the mortality reported for the non-mediastinitis patients (8.1\% vs. $2.3 \%)$. Having reviewed professional literature and 13 other risk-evaluating studies, Milano prospectively collected data on 20 preoperative and intraoperative variables on 6459 consecutive patients who underwent CABG and identified four highly significant independent predictors for the development of sternal dehiscence and mediastinitis (Milano et al., 1995). Losanoff and colleagues in their comprehensive review also analyzed identifiable risks that may serve as reliable predictors of sternal wound infection (Losanoff et al., 2002).

\begin{tabular}{|ll|}
\hline - & Obesity \\
\hline - & Congestive heart failure \\
\hline - & Previous heart surgery \\
\hline - & Duration of the surgical procedure \\
\hline - & Diabetes mellitus \\
\hline - & Chronic obstructive airway disease \\
\hline - & Smoking \\
\hline - & Larger female breast size \\
\hline
\end{tabular}

Table 1. Predictors of Deep Sternal Wound Infection:

22 Carmelo A. Milano, MD; Karen Kesler, MS; Nancy Archibald, MHA, MBA; Daniel J. Sexton, MD; Robert H. Jones, MD. “Mediastinitis After Coronary Artery Bypass Graft Surgery."Circulation. 1995;92:2245-2251 doi: 10.1161/01.CIR.92.8.2245

${ }^{23}$ Lamm P., Gödje O.L., Lange T., Reichart B. "Reduction of wound healing problems after median sternotomy by use of retention sutures." Ann Thorac Surg 1998;66:2125-2126 
Milano's study and his review of the relevant literature suggest that obesity and duration of surgery are the most important predictors of mediastinitis. Furthermore, his study documents for the first time that post-operative mediastinitis has a significant negative influence on long-term survival independent of the patient's preoperative condition.

\subsection{Infection risk factors in orthopedic and neurosurgical procedures}

Spinal and orthopedic surgery carries its own systemic risks (Kanafani et al., 2006).24 There are multiple factors, such as immunodeficiency, immunosuppression, diabetes, existing implants, malnutrition, and others, that may increase arthroplasty patient's risk of bacteremia and hematogenous total join infection following an invasive procedure (AAOS, 2010). A number of factors, including lymphopenia, duration of surgical procedure, and others, increase the risk of infection in spinal surgery patients (Kanafani et al., 2006; Watters et al., 2007). Given the potential adverse outcomes of joint and spinal infections -- both the human toll and the cost of treating spinal complications, infected joint replacements or infections - antibiotic prophylaxis is recommended in combination with patient risk assessment.

\begin{tabular}{|ll|}
\hline - & Existing prosthetic joint replacement \\
\hline - & Immunocompromised/immunosuppressed patients \\
\hline - & Inflammatory arthropathies (e.g.: rheumatoid arthritis, systemic lupus erythematosus) \\
\hline - & Radiation-induced immunosuppression \\
\hline - & Presence of co-morbidities (e.g.: diabetes, obesity, HIV, smoking) \\
\hline - & Previous prosthetic joint infections \\
\hline - & Malnourishment \\
\hline - & Hemophilia \\
\hline - & HIV infection \\
\hline - & Insulin-dependent (Type 1) diabetes \\
\hline - & Malignancy \\
\hline$\bullet$ & Megaprostheses \\
\hline$\bullet$ & Lymphopenia \\
\hline$\bullet$ & History of chronic infections \\
\hline
\end{tabular}

Table 2. Risk Factors for Postoperative Hematogeneous or Direct-Inoculation Infection of the Spine or Joints 25

\footnotetext{
${ }^{24}$ Kanafani ZA, Dakdouki GK, El-Dbouni O, Bawwab T, Kanj SS. "Surgical site infections following spinal surgery at a tertiary care center in Lebanon: incidence, microbiology, and risk factors." Scand J Infect Dis. 2006;38(8):589-592.

${ }_{25}$ Compiled based on Kanafani et al. (2006), AAOS recommendations (revised 2010), and NASS Guidelines (2007)
} 


\subsection{Excessive bleeding and duration of surgical procedure as infection risk factors}

Although cardiac patient's weight and other health conditions at the time of the operation may be beyond the surgeon's control, the duration of the surgical procedure depends, among other factors, on the management of bone and soft tissue bleeding (Samudrala, 2008). Similarly, in spinal and orthopedic surgery, the myriad systemic risks the patient brings into the operating room cannot be altered by the surgeon, but the duration of each procedure can - it is affected by clear visualization of the site of incision, which in turn depends on the management of bleeding.

Both the spine and the sternum are highly vascular bones. Appropriate hemostasis methods significantly improve the visibility of the surgical site and therefore help shorten the time it takes to perform any given surgical procedure - and reduce the risks associated with the length of spinal or cardiac operations.

\section{Bone wax as a modifiable risk factor for osteomyelitis, inflammation, and inhibited bone healing}

\subsection{Modifiable risk factors}

Risk factors for Osteomyelitis include a variety of systemic aspects ranging from cigarette smoking and malnutrition to immunosuppression, and osteoporosis, none of which can be controlled by the surgeon. However, risk factors under the surgeon's control can also predispose a patient to surgical complications and Osteomyelitis. Careful reassessment of all known modifiable risk factors is necessary to help prevent the incidence of post-operative surgical site infections. Prevention is especially important given the prevalence of infections caused by antibiotic-resistant organisms. This reassessment of risk should include a careful look at the management of bone bleeding.

\subsection{Role of bone hemostasis materials in preventable complications}

Management of bone bleeding involves a decision about what to avoid and what to introduce into the operating site. But the choice of bone hemostasis material may also prove critical in determining the effectiveness of topical antibiotic prophylaxis. Researchers have isolated multiple systemic risk factors contributing to surgical site complications in procedures involving the bone, but the published clinical studies often do not mention the type of bone hemostasis material used in the trials, and consequently exclude them from perioperative risk assesments. And yet, some bone hemostats, such as bone wax, may by virtue of their properties and their very presence in the surgical wound increase the risk of complications (Szerafin et al, 1999). ${ }^{26} \mathrm{~A}$ foreign body introduced into the surgical site can become a nidus of infection, lead to chronic inflammation, and interfere with the bones' reparative processes, thereby undermining any benefit antibiotic prophylaxis, especially topical applications, may have for the clinical outcome.

26 Szerafin and colleagues link the absence of bone wax to reduced instances of mediastinitis: "Nontraumatic surgical techniques, with limited use of electrocautery and without applying bone wax, remain the most important factors in the prevention [of mediastinitis]." In: Szerafin Tamás, MD, Osama Jaber, MD, Árpád Péterffy, MD, PhD. "Reduction of wound healing problems after median sternotomy (letter to the editor)." Ann Thorac Surg 1999; 68: 2388. 


\subsubsection{Bone wax as bone hemostasis material}

Bone wax, composed of beeswax and softening agents, has been widely used for over one hundred years. Unadulterated beeswax was used for amputation hemostasis during the US Civil War. The development of modern softened bone wax has been attributed to Victor Horsley in 1892 (Horsley, 1892; Parker, 1892). ${ }^{27}$

In the 1924 edition of Carson's Modern Operative Surgery, the use of bone wax is recommended not for bone hemostasis - the currently prevalent application -- but for preventing bone healing and for the creation of a pseudoarthrosis (Verral, 1924). ${ }^{28}$ Since 1924, there has not been a significant change in the formulation of bone wax. The material is still comprised of insoluble and non-resorbable beeswax softened with paraffin and/or isopropyl palmitate (Schonauer et al., 2004). ${ }^{29}$ Bone wax has no inherent hemostatic quality, and its effect on the bone remains consistent with Carson's description.

The material's appeal is in its ease of use and its ability to effectively tamponade the vascular spaces in the bone, stopping bleeding immediately. Contrary to Carson's recommendation, it is being used in procedures such as median sternotomy or spinal fusion, in which bone fusion and healing are required -- and in which pseudoarthrosis, or a failure of callus formation resulting in a non-osseous union of bone fragments, is the precise opposite of the desired surgical outcome.

Although effective in stopping bone bleeding, bone wax has troublesome adverse effects. Once applied to the bone, the material remains at the surgical site indefinitely. It may become a nidus of infection and if contaminated, it may cause infection of the soft tissue or osteomyelitis (Allison, 1994; Chun et al., 1988; Finn et al., 1992; Gibbs et al., 2004; Johnson et al., 1981; Nelson et al., 1990; Wellisz et al., 2006, 2008a, 2008b).

\subsubsection{Inflammation and bone wax}

Bone wax remains at the site of application indefinitely and can cause giant cell formation as well as local inflammation of the surrounding tissue (Allison, 1994).30 Sorrenti et al. evaluated the reactions to bone wax in human tibias in 12 patients who had undergone tibial tubercle elevation. The patients underwent re-operation after 5 to 13 months, and bone biopsies were performed. A progressive reaction was described that began with a foreign body giant cell reaction with giant cells containing vacuoles filled with bone wax, to the formation of mature fibrous tissue. Reactions to bone wax consisted mainly of pain and swelling, often exacerbated by infection (Sorrenti, 1984). ${ }^{31}$ Alberius et al. utilized a rat

27 Horsley, V. (1892). “Antiseptic wax [Letter]." Br Med J 1: 1165. Parker, R. (1892). “Aural pyaemia siccessfully treated by removing putrid thrombus of jugular vein and lateral sinus." The British Medical Journal 1: 1076-1077

${ }^{28}$ Verrall, P. J. (1924). “Operation on Joints.” Modern Operative Surgery. H. W. Carson. London, Cassell \& Co. . 1: 69 .

${ }^{29}$ Schonauer C, Tessitore E, Barbagallo G, Albanese V, Moraci A. "The use of local agents: bone wax, gelatin, collagen, oxidized cellulose." Eur Spine J. 2004;13 (suppl 1):S89-S96.

30 Allison RT. "Foreign body reactions and an associated histological artefact due to bone wax." $\mathrm{Br} J$ Biomed Sci 1994;51:14-7.

${ }^{31}$ Sorrenti SJ, Cumming WJ, Miller D. "Reaction of the human tibia to bone wax." Clin Orthop Relat Res 1984:293-6. 
calvarial bone model to identify the three stages of inflammatory reaction to bone wax: 1) a nonspecific inflammatory response; 2) a foreign body reaction; and 3) a marked fibrous reaction (Alberius et al., 1987). ${ }^{32}$ The observation is consistent with histologic findings associated with the implantation of bone wax in a rat tibia model, which typically include foreign-body reactions characterized by giant cells, plasma cells, fibrous tissue, and a lack of bone formation (Howard \& Kelley, 1969). ${ }^{33}$

The inflammatory reactions to bone wax may also be a source of post-operative pain. A report from Norway described seven patients with intractable pain following the use of bone wax in foot surgery (Anfinsen et al., 1993). ${ }^{34}$ Five of the patients were pain-free after the bone containing the inflamed bone wax was resected. Anecdotal reports describing adverse inflammatory reactions to bone wax are also common (Allison 1994; Anfinsen et al. 1993; Angelini et al., 1987; Ates et al., 2004; Aurelio et al., 1984; Bolger et al., 2005; Chun, et al., 1988; Cirak \& Unal 2000; Hadeishi et al., 1995; Julsrud, 1980; Katz\& Rootman, 1996; Kothbauer et al., 2001; Low \& Sim 2002; Patel et al., 2000; Verborg et al., 2000; Wolvius \& van der Wal 2003;). ${ }^{35}$ Reactions consist mainly of pain and swelling, often exacerbated by infection.

\subsubsection{Infection and bone wax}

There is evidence that bone wax not only remains at the surgical site indefinitely but also actually increases infection rates. Researchers Johnson and Fromm found that in a rabbit iliac crest defect model bone wax decreases the natural ability of bone to clear bacteria

32 Alberius, P., B. Klinge, et al. (1987). "Effects of bone wax on rabbit cranial bone lesions." J Craniomaxillofac Surg 15(2): 63-67.

${ }^{33}$ Howard TC, Kelley RR. "The effect of bone wax on the healing of experimental rat tibial lesions." Clin Orthop Relat Res 1969; 63:226 -32.

${ }^{34}$ Anfinsen, O. G., B. Sudmann, et al. (1993). "Complications secondary to the use of standard bone wax in seven patients." J Foot Ankle Surg 32(5): 505-508.

35 See: Allison, 1994; Anfinsen et al. 1993; Angelini, el-Ghamari, et al. "Poststernotomy pseudo-arthrosis due to foreign body reaction to bone wax." Eur J Cardiothorac Surg 1987; 1(2): 129-130.et al., 1987; Ates, O., S. R. Cayli, et al. 2004. "Bone wax can cause foreign body granuloma in the medulla oblongata." $\mathrm{Br} J$ Neurosurg 2004; 18(5): 538-540. Aurelio, J., B. Chenail, et al. “Foreign-body reaction to bone wax. Report of a case." Oral Surg Oral Med Oral Pathol 1984; 58(1): 98-100. Bolger WE, Tadros M, et al. "Endoscopic management of cerebrospinal fluid leak associated with the use of bone wax in skull-base surgery." Otolaryngol Head Neck Surg 2005; 132(3): 418-420. Chun PK, Virmani R, et al. "Bone wax granuloma causing saphenous vein graft thrombosis." Am Heart J 1988; 115(6): 1310-1313. et al., 1988; Cirak B \& Unal O. "Iatrogenic quadriplegia and bone wax. Case illustration." J Neurosurg 2000; 92(2 Suppl): 248.; Hadeishi H., N. Yasui, et al. (1995). "Mastoid canal and migrated bone wax in the sigmoid sinus: technical report." Nurosurgery 1995; 36(6): 1220-1223; discussion 1223-1224;. Julsrud, ME (1980). "A surgical complication: allergic reaction to bone wax." J Foot Surg 1980; 19(3): 152-154.Katz SE \& Rootman J. “Adverse effects of bone wax in surgery of the orbit." Ophthal Plast Reconstr Surg 1996; 12(2): 121-126., 1996; Kothbauer KF, Jallo GI, et al. "Foreign body reaction to hemostatic materials mimicking recurrent brain tumor. Report of three cases." J Neurosurg 2001; 95(3): 503-506.; Low WK \& Sim CS. "Bone wax foreign body granuloma in the mastoid." ORL J Otorhinolaryngol Relat Spec 2002; 64(1): 38-40.; Patel RB et al. "Bone wax as a cause of foreign body granuloma in the cerebellopontine angle. Case illustration." J Neurosurg 2000; 92(2): 362.; VerborgOK et al. "A retroperitoneal tumor a. s a late complication of the use of bone wax." Acta Orthop Belg2000; 66(4): 389-391.; Wolvius EB \& van der Wal KG "Bone wax as a cause of a foreign body granuloma in a cranial defect: a case report." Int J Oral Maxillofac Surg 2003; 32(6): 656-658.; 
(Johnson \& Fromm, 1981).36 In a rat tibia model, Nelson and colleagues observed that the presence of bone wax reduced the amount of Staphylococcus aureus needed to produce osteomyelitis by a factor of 10,000 (Nelson et al., 1990), a finding that is particularly alarming given the growing prevalence of the methicillin-resistant Staph. aureus. In a clinical study of spinal procedures conducted by Gibbs and colleagues, infection rates following spinal surgery increased ten-fold - 1 in 7 vs. 1 in 72 infections -- when bone wax was used for bone hemostasis (Gibbs et al., 2004). ${ }^{37}$ Similarly, researchers observed that bone wax increased the risk of mediastinitis following sternotomies performed during cardiac procedures (El Oakley, 1996; Fynn-Thompson et. al., 2004; Hollenbeak et. al., 2000; Losanoff et al., 2002; Szerafin et al., 1999). 38

\subsubsection{Bone wax and bone healing}

The healing potential of bone, whether subject to trauma or surgery, is influenced by a variety of biochemical, biomechanical, cellular, hormonal, and pathological processes. The cellular components of bone consist of osteogenic precursor cells, osteoblasts, osteoclasts, osteocytes, and the hematopoietic elements of bone marrow, all of which are integral to new bone formation and regeneration. When applied to the cut or resected surface of the bone, whether sternal, vertebral, cranial, or other, traditional bone wax inhibits bone healing by interfering with the formation of new bone (osteogenesis).

\subsubsection{Bone wax and inhibition of new bone formation}

Living bone is in a constant state of bone deposition, resorption, and remodeling. This continuously occurring natural cycle of creation, destruction, and re-shaping of the osseous tissue is what facilitates the bone healing process (Kalfas, 2001). ${ }^{39}$ Bone wax not only compromises the bone's ability to heal by increasing the risk of osteomyelitis (Gibbs et al., 2004), but it also interferes with healing directly by disrupting the regenerative processes necessary to achieve an osseous fusion after surgery.

Bone healing occurs in three distinct but overlapping stages: 1) the early inflammatory stage, when hematoma forms and granulation occurs; 2) the repair stage, in which cartilage and callus replace hematoma; and 3) the late remodeling stage, in which the bone regains its shape, circulation improves, and mechanical strength returns (Kalfas, 2001).

The first 1 to 2 weeks are a period in which inflammation and revascularization occur. During the first few hours and days, inflammatory cells and fibroblasts infiltrate the bone, which results in the formation of granulation tissue, ingrowth of vascular tissue, and migration of mesenchymal cells. The mesenchymal cells then differentiate into osteoblasts and osteoclasts.

\footnotetext{
${ }^{36}$ Johnson P, Fromm D. “Effects of bone wax on bacterial clearance." Surgery 1981;89:206- 209

${ }^{37}$ Gibbs L, Kakis A, Weinstein P, et al. "Bone wax as a risk factor for surgical-site infection following neurospinal surgery." Infect Control Hosp Epidemiol 2004; 25:346Y348

${ }^{38}$ El Oakley RM, Wright JE. "Postoperative mediastinitis: classification and management." Ann Thorac Surg 1996;61:1030-6. Fynn-Thompson F, Vander Salm TJ. "Methods for reduction of sternal wound infection." Semin Thorac Cardiovasc Surg 2004;16:77-80. Hollenbeak CS, Murphy DM, Koenig S, Woodward RS, Dunagan WC, Fraser VJ. "The clinical and economic impact of deep chest surgical site infections following coronary artery bypass graft surgery." Chest 2000;118:397-402.

${ }^{39}$ Kalfas, I.H., MD. “Principles of Bone Healing." Neurosurg Focus 2001; 10 (4):Article 1, p. 7-10
} 
Osteoblasts are mature, metabolically active bone forming cells, which arise from osteoprogenitor cells located in the deeper layer of periosteum and the bone marrow. They secrete osteoid, the unmineralized organic matrix that subsequently undergoes mineralization, giving the bone its strength and rigidity. As their bone forming activity nears completion, some osteoblasts are converted into osteocytes whereas others remain on the periosteal or endosteal surfaces of bone as lining cells. Osteoblasts also play a role in the activation of bone resorption by osteoclasts, setting the stage for later bone remodeling. 40

\subsubsection{Bone wax and inhibition of bone fusion}

With the application of a thin layer of bone wax on a cut surface of the bone, even if bone wax has been applied and then scraped off, interference with bone healing occurs. A group of researchers demonstrated in 1969 that bone wax prevents bone healing in an animal model and concluded that bone wax is contraindicated in areas where bone fusion is desired (Howard \& Kelley, 1969).41 In the clinical setting, autopsy studies have demonstrated persistent sternal nonunion attributed to the presence of bone wax (Sudman et al., 2006). ${ }^{42}$ Sternal bone nonunion after cardiac surgery is almost always associated with concomitant mediastinitis (Losanoff et al., 2002; El Oakley \& Wright, 1996).

Sternal nonunion observed by Sudman and colleagues was accompanied by chronic inflammatory reactions with the presence of residual bone wax up to 10 years after median sternotomy procedure (Sudman et al., 2006).

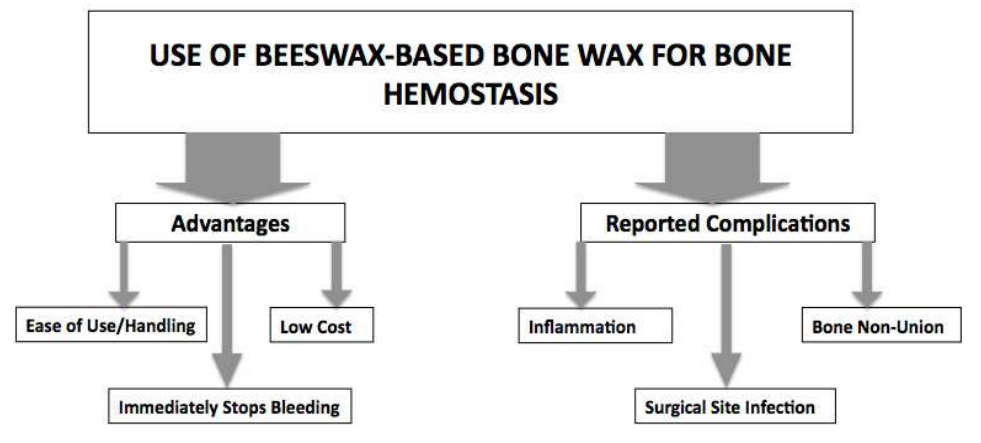

Fig. 1. Bone Wax Advantages and Complications

Solheim and colleagues examined the properties of local hemostats for osseous tissue, assuming that, to be effective, the materials should be absorbable, biocompatible and should not inhibit osteogenesis. They evaluated different local hemostats by observing tissue response and effect on demineralized bone-induced heterotopic osteogenesis in the abdominal muscle of 120 rats. Non-absorbable bone wax of $88 \%$ beeswax and absorbable

40 See: Copenhaver WM, Kelly DE, Wood RL: “The connective tissues: cartilage and bone," in Copenhaver WM, Kelly DE, Wood RL (eds): Bailey's Textbook of Histology, ed 17. Baltimore: Williams \& Wilkins, 1978, pp 170-205; Recker RR: “Embryology, anatomy, and microstructure of bone," in Coe FL, Favus MJ (eds): Disorders of Bone and Mineral Metabolism. New York: Raven, 1992, pp 219-240.

${ }^{41}$ Howard TC, Kelley RR. "The effect of bone wax on the healing of experimental rat tibial lesions." Clin Orthop Relat Res 1969; 63:226 -32.

42 Sudmann B, Bang G, Sudmann E. "Histologically verified bone wax (beeswax) granuloma after median sternotomy in 17 of 18 autopsy cases." Pathology 2006; 38:138-41. 
bovine fibrin-collagen paste both significantly inhibited osteoinduction, whereas a bioerodible polyorthoester drug delivery system with or without $4 \%$ gentamicin did not. Bone wax was not absorbed and induced a chronic foreign body reaction. Fibrin-collagen paste induced less inflammation with numerous monocytes and macrophages with engulfed material. Bioerodible polyorthoester caused a very moderate tissue reaction and was mostly resorbed after four weeks (Solheim et al., 1992). ${ }^{43}$

Despite its good handling and effectiveness in stopping bone bleeding instantly, the longterm complications associated with the use of traditional bone wax far outweigh its usefulness as a bone hemostasis material. Although for its ease of use and effectiveness in surgery it remains the most commonly used bone hemostasis material, given its ties to widely reported complications, a variety of alternative bone bleeding management methods have been developed.

\section{Alternative bone hemostasis materials and methods}

\subsection{Surgical technique and management of bone bleeding}

Management of bleeding is an integral aspect of the surgical technique. One of the options available to the surgeon operating on the osseous tissue is a mechanical barrier, such as that created by bone wax, which works to occlude bleeding from the open channels of the bone. In soft tissue hemostasis, surgeons most frequently chose electrocautery, a technique in which heat causes capillaries and small blood vessels to collapse and seal. Cushing first reported the use of this technique in 1921, after he used it in neurosurgical procedures. Electrocautery has since become a common hemostatic tool in modern surgery across all specialties, becoming a soft tissue corollary to bone wax.

\subsubsection{Electrocautery and bone hemostasis}

Electrocautery works through a pulsating (or intermittent) wave delivered to the surgical site by a unipolar device causing tissue dehydration and vessel thrombosis (Neumayer, 2008). ${ }^{44}$ Despite the structural differences between soft tissue and cut bone surfaces, electrocautery is commonly used for both. The thermal settings used to seal bleeding vessels are generally ineffective in stemming bleeding from open vascular channels in the bone. Higher heat settings can stop bone bleeding, but burning tissue to the sufficient degree for a charred coagulum physically to block blood flow damages osseous tissue, interferes with bone healing, and increases the incidence of postoperative infection. Excessive use of this technique for bone should be avoided. (El Oakley et al., 1996; Tang et al., 2004; Nelson et. al., 1990; Nishida et al., 1991).45

\footnotetext{
${ }^{43}$ Solheim E, Pinholt EM, Bang G, Sudmann E. "Effect of local hemostatics on bone induction in rats: a comparative study of bone wax, fibrin-collagen paste, and bioerodible polyorthoester with and without gentamicin." J Biomed Mater Res. 1992 Jun;26(6):791-800.

44 Neumayer, L., Vargo, D. (2008) "Principles of Preoperative and Operative Surgery", In: Townsend: Sabiston Textbook of Surgery, 18th ed. Courtney M. Townsend Jr. R. Daniel Beauchamp B. Mark Evers, Kenneth L. Mattox, pp. (251-279), Saunders Elsevier, 978-1-4160-3675-3, Philadelphia, PA

${ }^{45}$ El Oakley RM, Wright JE. "Postoperative mediastinitis: classification and management." Ann Thorac Surg 1996;61:1030-6.
} 


\subsubsection{Hemostasis through natural clotting}

Another approach to bone Hemostasis is to let the bone bleed throughout the surgery. In this way, the surgeon does not introduce any foreign materials into the site and allows the bleeding bone to clot naturally. However, research has shown that the risks of unnecessary bleeding include increased blood loss and the costs and multiple risks associated with blood transfusions (Rogers et al, 2009). ${ }^{46}$ Median sternotomies cause heavy bleeding, and complex spinal reconstructive procedures are invariably associated with excessive intraoperative blood loss, which significantly increases the risk of severe perioperative complications (Block, 2005). ${ }^{47}$ Samudrala summarizes the benefits of effective hemostasis, which include decreased morbidity and mortality, fewer transfusions, reduced surgical time, better visualization of the surgical field - and, above all, better surgical outcome (Samudrala, 2008). ${ }^{4}$

\subsection{Topical bone hemostats}

\subsubsection{Mechanical barrier}

Topical hemostatic agents are mechanical barriers routinely used to achieve hemostasis of cancellous bone surfaces during neurological, cardio-thoracic, orthopedic, maxillofacial, and a variety of other surgical procedures, including procurement of bone graft material from the iliac crest. A mechanical barrier works to occlude bleeding from the open channels of the bone, the way bone wax does. The topical hemostatic agents developed as an alternative to bone wax have various active ingredients and mechanisms of actions, thus affecting hemostasis and bone healing differently.

\subsubsection{Synthetic tamponade}

A common method of occluding bleeding used strictly for the vascular surface of cut or resected bone is a tamponade, which creates a physical barrier that stops blood flow by blocking osseous blood channels, the way bone wax does. Tamponade materials are beneficial to the surgeon by providing hemostasis that is both immediate and easy to apply. Products in this group are direct alternatives to bone wax and offer many of the same benefits, but not the risks. Physical barriers are applied directly to the bone, can be shaped to the surgeon's needs and work immediately. While bone wax remains at the site of application indefinitely creating a host of problems, newer products made of water-soluble

Nelson DR, Buxton TB, Luu QN, Rissing JP. "The promotional effect of bone wax on experimental Staphylococcus aureus osteomyelitis." J Thorac Cardiovasc Surg 1990;99:977-80.

Nishida H, Grooters RK, Soltanzadeh H, Thieman KC, Schneider RF, Kim WP. "Discriminate use of electrocautery on the median sternotomy incision. A $0.16 \%$ wound infection rate." J Thorac Cardiovasc Surg 1991;101:488-94.

Tang GH, Maganti M, Weisel RD, Borger MA. "Prevention and management of deep sternal wound infection." Semin Thorac Cardiovasc Surg 2004;16:62-9.

${ }^{46}$ Rogers MA, Blumberg N, Saint S, Langa KM, Nallamothu BK. "Hospital variation in transfusion and infection after cardiac surgery: a cohort study." BMC Med 2009;7:37.

47 Block JE.. "Severe blood loss during spinal reconstructive procedures: the potential usefulness of topical hemostatic agents." Med Hypotheses. 2005; 65(3):617-21

${ }^{48}$ Samudrala, S.. “Topical Hem static Agents in Surgery: A Surgeon's Perspective." AORN Journal, 2008. Supplement: Intraoperative Bleeding and Hemostasis in Surgical Procedures. vol. 88, no 3: p. S2-11 
alkylene oxide copolymers (AOC) provide immediate hemostasis but remain at the site for less than 48 hours (Magyar et. al., 2008). ${ }^{49}$ These copolymers are inert, and they are eliminated from the body unmetabolized via the kidneys and liver. Recent research in animal models has shown that AOC based product does not increase infection rates, does not promote inflammation, and does not interfere with bone healing (Armstrong, 2010; Magyar et al., 2008; Sawan et al., 2010; Wellisz et al. 2006, 2008a, 2008b). ${ }^{50}$ An AOC based bone hemostasis material (Ostene ${ }^{\circledR}$ ) has been available since 2006 and is currently distributed by Baxter International, Inc.

\subsection{Soft tissue hemostats}

Bleeding from bone can also be controlled with soft tissue hemostats. Soft tissue hemostasis materials can aid in the activation of the body's natural clotting mechanism. Unlike bone wax, soft tissue hemostats are made from a range of resorbable ingredients. These ingredients, discussed more fully below, take anywhere from days to months to resorb.

\subsubsection{Gelatin}

Gelatin based agents are generally made from animal skin gelatin mixed and baked into a sponge, powder, or a film. These materials work by creating a physical matrix followed by swelling of the material to control bleeding. Gelatin sponges are non-absorbable and can expand up to $200 \%$ of their initial volume. If left in the wound, they may act as a nidus for infection and abscess formation (Lindstrom, 1956). ${ }^{51}$ Gelatin-based agents have also been reported to delay bone healing (Schonauer et al, 2004). ${ }^{52}$

\subsubsection{Thrombin}

Thrombin is derived from either bovine or human sources. It provides hemostasis in soft tissue by converting fibrinogen to fibrin to form clots and activate clotting factors. Thrombin

\footnotetext{
${ }^{49}$ Magyar CE, Aghaloo TL, Atti E, Tetradis S." Ostene, a new alkylene oxide copolymer bone hemostatic material, does not inhibit bone healing." Neurosurgery 2008;63:373-8; discussion 8 .

50 Armstrong et al. BMC Surgery 2010, 10:37 http://www.biomedcentral.com/1471-2482/10/37., Magyar CE, Aghaloo TL, Atti E, Tetradis S. "Ostene, a new alkylene oxide copolymer bone hemostatic material, does not inhibit bone healing." Neurosurgery 2008;63:373-8; discussion 8., Sawan A, Elhawary Y, Zaghlool Amer M, \& Abdel Rahman M. "Controversial Role of Two Different Local Haemostatic Agents on Bone Healing." Journal of American Science, 2010; 6(12):155-163]. (ISSN: 1545-1003., Wellisz T, Armstrong JK, Cambridge J, Fisher TC: "Ostene, a new water-soluble bone hemostasis agent." J Craniofac Surg 17: 420-425, 2006. Wellisz T, An YH, Wen X, Kang Q, Hill CM, Armstrong JK. "Infection rates and healing using bone wax and a soluble polymer material." Clin Orthop Relat Res 2008; 466:481-6. Wellisz T, Armstrong JK, Cambridge J, et al. "The effects of a soluble polymer and bone wax on sternal healing in an animal model." Ann Thorac Surg 2008; 85:1776-80;

${ }^{51}$ Lindstrom, P.A., "Complications from the use of absorbable hemostatic sponges." AMA Arch Surg. 1956; Iss. 73, pp. 133-141

52 Schonauer C, Tessitore E, Barbagallo G, Albanese V, Moraci A. “The use of local agents: bone wax, gelatin, collagen, oxidized cellulose." Eur Spine J. 2004;13 (suppl 1):S89-S96.Shearwood McClelland III, "Postoperative intracranial neurosurgery infection rates in North America versus Europe: A systematic analysis." Am J Infect Control 2008; 36:570-3
} 
works quickly and is easy to use. However, bovine thrombin has been known to trigger immunologic reactions (Achneck et. al., 2010). ${ }^{53}$

Thrombin is commonly mixed with a gelatin sponge for areas with heavier bleeding. This product is effective because the gelatin ingredient works as a physical matrix while the thrombin works within the clotting cascade. The issues associated with this product include swelling, and it needs contact with fibrinogen in order to work (Achneck et. al., 2010).

\subsubsection{Oxidized Regenerated Cellulose (ORC)}

Oxidized regenerated cellulose-based products are sold in sheets and act as a physical matrix that promotes the initiation of clotting. ORC also works by swelling and gel formation, as well as surface interactions with proteins, platelets and intrinsic and extrinsic pathway activation (Schonauer, 2004). The low PH of this product is shown to have an antimicrobial effect. However, the acidity may cause inflammation of surrounding tissue and interfere with healing (Tomizawa, 2005). ${ }^{4}$ ORC has also been shown to promote a foreign body reaction and reduce bone repair in rat studies (Geary \& Frantz, 1950; Ibarrola et al., 1985). 55

\subsubsection{Collagen}

Microfibrillar Collagen is derived from bovine corium. It is available as flour, foam, and in sheets. These products work by initiating platelet adherence and activation of the clotting cascade. Though some proved promising in their ability to promote clotting in reconstructive spinal surgery (Block, 2005)56, collagen-based products are associated with infection and delayed bone healing (Armstrong et al., 2008). Inflammation and residual material upon resection at up to 90 days have been found by Barbolt et al. (2001) ${ }^{57}$ and Ereth et al. (2008). 58

\subsubsection{Fibrin}

Fibrin sealants are made up of two parts, thrombin (human) and fibrinogen, that are combined at the time of surgery. They work by inducing platelet aggregation and initiating the clotting cascade when applied directly to bleeding bony sites. The fibrinogen determines

\footnotetext{
${ }^{53}$ Achneck HE, Sileshi B, Jamiolkowski RM, Albala DM, Shapiro ML, Lawson JH. "A comprehensive review of topical hemostatic agents: efficacy and recommendations for use." Ann Surg 2010;251:217-28.

54 Tomizawa Y. "Clinical benefits and risk analysis of topical hemostats: a review." J Artif Organs 2005;8:137-42.

${ }_{55}$ Geary JR, Kneeland Frantz V. "New absorbable hemostatic bone wax; experimental and clinical studies." Ann Surg 1950;132:1128-37., Ibarrola JL, Bjorenson JE, Austin BP, Gerstein H. "Osseous reactions to three hemostatic agents." J Endod 1985;11:75-83.

${ }_{56}$ Block JE.."Severe blood loss during spinal reconstructive procedures: the potential usefulness of topical hemostatic agents." Med Hypotheses. 2005; 65(3):617-21

${ }^{57}$ Barbolt TA, Odin M, Leger M, Kangas L. "Pre-clinical subdural tissue reaction and absorption study of absorbable hemostatic devices." Neurol Res 2001;23:537-42.

${ }^{58}$ Ereth MH, Schaff M, Ericson EF, Wetjen NM, Nuttall GA, Oliver WC, Jr. "Comparative safety and efficacy of topical hemostatic agents in a rat neurosurgical model." Neurosurgery 2008;63:369-72; discussion 72 .
} 
the mechanical strength of the sealant, while the thrombin concentration determines the rapidity of the clot (Achneck et al., 2010). ${ }^{59}$ Fibrin sealants are most frequently used for soft tissue hemostasis, but they have also been used for bone bleeding control during osseous tissue repair. Fibrin sealants are often used as an adjunct to other hemostasis materials.

\subsubsection{Platelet Rich Plasma (PRP)}

Platelet rich plasma (PRP) that is derived from the patient is also used in surgery for bone hemostasis. PRP is derived from the patient's own blood by separating red blood cells from the fibrin and plasma in a centrifuge. The plasma, which forms a gel, is applied where hemostasis is needed. This technique relies on growth factors that trigger early wound healing said to be present in the PRP. The true benefit for PRP in bone hemostasis has yet to be demonstrated (Griffin et al. 2008) ${ }^{60}$, and the technique has shown to be a markedly expensive bone hemostasis alternative. Moreover, like all the other soft tissue hemostats, platelet rich plasma cannot replicate the handling and immediate hemostasis effect of bone wax, which many topical bone hemostasis materials seek to offer.

\subsection{Topical bone hemostats - towards a comparative analysis}

Few comparative studies of topical bone hemostasis materials have been published to date. Although more research and clinical data would help the surgeons navigate the field of available alternatives to bone wax more effectively and assess their merits more thoroughly, a comparative analysis is beginning to emerge. Because bone healing and the risk of infection are the main complications associated with bone wax, in their comparative studies of management of bone bleeding alternatives, the researchers tend to focus on new bone formation and osteomyelitis without losing sight of the materials' effectiveness as hemostats.

\subsubsection{Studies of new bone formation and healing with topical bone hemostats}

In 1992, Solheim and colleagues examined traditional bone wax, absorbable bovine fibrincollagen paste, and a bioerodible polyorthoester drug delivery system. They concluded that, of the three bone hemostatics under scrutiny, polyorthoester alone did not significantly inhibit osteoinduction and, after causing a very moderate tissue reaction, was mostly resorbed at the end of week four of the study (Solheim et al., 1992).

In a 1992 comparative study, Finn and colleagues evaluated the potential for bone regeneration in the presence of four common hemostatic materials in a dog model in a manner that parallels iliac bone procurement in humans in oral and maxillofacial surgery. The agents compared were Avitene (microfibrillar collagen; Medchem Products, Inc, Woburn, MA); bone wax (beeswax with isopropyl palmitate; Ethicon, Inc, Somerville, NJ); Gelfoam (absorbable gelatin sponge; The Upjohn Company, Kalamazoo, MI); and Surgicel (oxidized regenerated cellulose; Johnson \& Johnson Products, Inc, Patient Care Division, New Brunswick, NJ). Five surgical defects were created in each dog for placement of the

${ }^{60}$ Griffin XL, Smith CM, Costa ML. "The clinical use of platelet-rich plasma in the promotion of bone healing: a systematic review." Injury 2009;40:158-62. 


\begin{tabular}{|c|c|c|c|c|c|c|c|}
\hline $\begin{array}{l}\text { Princi- } \\
\text { pal } \\
\text { Agent }\end{array}$ & \begin{tabular}{|l|} 
ALKYLENE \\
OXIDE \\
COPOLYMERS
\end{tabular} & $\begin{array}{l}\text { MICROFIBRILLA } \\
\text { R COLLAGEN }\end{array}$ & GELATIN & THROMBIN & \begin{tabular}{|l} 
GELATIN \\
GRANULES \\
THROMBIN
\end{tabular} & \begin{tabular}{|l|} 
OXIDIZED \\
REGENERA \\
TED \\
CELLULOSE
\end{tabular} & BEESWAX \\
\hline $\begin{array}{l}\text { Sup- } \\
\text { plied }\end{array}$ & $\begin{array}{l}1 \mathrm{~g}, 2.5 \mathrm{~g}, 3.5 \mathrm{~g} \\
\text { Bars }\end{array}$ & Sponge/flour & Sponge & \begin{tabular}{|l} 
Powder \\
/Solution
\end{tabular} & $\begin{array}{l}\text { Gel in } \\
\text { Syringe }\end{array}$ & $\begin{array}{l}\text { Pad/ } \\
\text { Sponge }\end{array}$ & 2.5g Bar \\
\hline Price+ & 2 & \begin{tabular}{|l} 
Flour 3 \\
Foam 4 \\
\end{tabular} & 2 & $\begin{array}{l}\text { Powder } 2 \\
\text { Solution } 3 \\
\end{array}$ & $\begin{array}{l}2 \mathrm{~mL} 2 \text { to } 3 \\
5 \mathrm{~mL} 4\end{array}$ & 2 & 1 \\
\hline $\begin{array}{l}\text { Ingre- } \\
\text { dients }\end{array}$ & $\begin{array}{l}\text { Water } \\
\text { Soluble } \\
\text { Synthetic } \\
\text { Copolymers }\end{array}$ & $\begin{array}{l}\text { Bovine } \\
\text { Corium } \\
\text { Collagen }\end{array}$ & $\begin{array}{l}\text { Animal } \\
\text { Gelatin }\end{array}$ & $\begin{array}{l}\text { Bovine } \\
\text { Thrombin }\end{array}$ & $\begin{array}{l}\text { Bovine } \\
\text { Gelatin } \\
\text { Bovine } \\
\text { Thrombin }\end{array}$ & $\begin{array}{l}\text { Wood } \\
\text { pulp }\end{array}$ & $\begin{array}{l}\text { Beeswax, } \\
\text { Vaseline, } \\
\text { Isopropyl } \\
\text { palmitate }\end{array}$ \\
\hline $\begin{array}{l}\text { Hemo- } \\
\text { static } \\
\text { Action }\end{array}$ & $\begin{array}{l}\text { Mechanical } \\
\text { occlusion }\end{array}$ & $\begin{array}{l}\text { Platelet } \\
\text { release } \\
\text { stimulation }\end{array}$ & $\begin{array}{l}\text { Mecha- } \\
\text { nical } \\
\text { occlusion } \\
\text { swells, gel } \\
\text { formation }\end{array}$ & $\begin{array}{l}\text { Activates } \\
\text { Fibrin }\end{array}$ & $\begin{array}{l}\text { Mechanical } \\
+ \text { Activates } \\
\text { Fibrin }\end{array}$ & $\begin{array}{l}\text { Mecha- } \\
\text { nical } \\
\text { occlusion } \\
\text { swells, gel } \\
\text { formation }\end{array}$ & $\begin{array}{l}\text { Mecha- } \\
\text { nical } \\
\text { occlusion }\end{array}$ \\
\hline $\begin{array}{l}\text { Time to } \\
\text { Hemo- } \\
\text { stasis }\end{array}$ & Immediate & $<10$ Minutes & $\begin{array}{l}2+ \\
\text { Minutes }\end{array}$ & $\begin{array}{l}2+ \\
\text { Minutes }\end{array}$ & $\begin{array}{l}1.5+ \\
\text { minutes }\end{array}$ & $\begin{array}{l}2+ \\
\text { Minutes }\end{array}$ & $\begin{array}{l}\text { Immed- } \\
\text { iate }\end{array}$ \\
\hline $\begin{array}{l}\text { Remains } \\
\text { at Site }\end{array}$ & 24-48 hours & $<12$ weeks & \begin{tabular}{|l}
$4-6$ \\
weeks
\end{tabular} & minutes & 6 - 8 weeks & 7-14 days & $\begin{array}{l}\text { Indefi- } \\
\text { nitely }\end{array}$ \\
\hline $\begin{array}{l}\text { Advant- } \\
\text { ages }\end{array}$ & $\begin{array}{l}\text {-Immediate } \\
\text { hemostasis } \\
\text { - Ease of use } \\
\text { - Adheres to } \\
\text { wet surfaces } \\
\text { - Dissolves }\end{array}$ & $\begin{array}{l}\text {-Immediate } \\
\text { hemostasis } \\
\text { - Binds to } \\
\text { surfaces } \\
\text { - Does not } \\
\text { swell }\end{array}$ & $\begin{array}{l}\text { - Binds to } \\
\text { surfaces }\end{array}$ & $\begin{array}{l}\text {-Improv- } \\
\text { es gelatin } \\
\text { sponge } \\
\text { perfor- } \\
\text { mance }\end{array}$ & $\begin{array}{l}\text {-Syringe } \\
\text { delivery } \\
\text { system }\end{array}$ & $\begin{array}{l}- \text { Bacterios } \\
\text { tatic }\end{array}$ & $\begin{array}{l}\bullet \text { Imme- } \\
\text { diate } \\
\text { hemo- } \\
\text { stasis } \\
\bullet \text { Ease of } \\
\text { use }\end{array}$ \\
\hline $\begin{array}{l}\text { Adverse } \\
\text { Effects }\end{array}$ & & $\begin{array}{l}\bullet \text { Interferes } \\
\text { with healing } \\
\text { - Allergic } \\
\text { reactions } \\
\bullet \text { Infection } \\
\text { - Adhesion } \\
\text { formation }\end{array}$ & $\begin{array}{l}\bullet \text { Interfer- } \\
\text { es with } \\
\text { healing } \\
\bullet \text { Swelling } \\
\bullet \text { Encapsul } \\
\text { ation of } \\
\text { fluid } \\
\text { • Foreign } \\
\text { body } \\
\text { reactions } \\
\bullet \text { Nidus } \\
\text { for } \\
\text { infection }\end{array}$ & $\begin{array}{l}\text { - Allergic } \\
\text { reactions } \\
\text { - Anti- } \\
\text { body } \\
\text { formation }\end{array}$ & $\begin{array}{l}\text { •Interferes } \\
\text { with } \\
\text { healing } \\
\text { • Swelling } \\
\text { - Foreign } \\
\text { body } \\
\text { reactions } \\
\text { • Nidus for } \\
\text { infection } \\
\text { - Antibody } \\
\text { formation }\end{array}$ & $\begin{array}{l}\bullet \text { Inter- } \\
\text { feres with } \\
\text { healing } \\
\text { - Swelling } \\
\text { - Foreign } \\
\text { body } \\
\text { reactions }\end{array}$ & $\begin{array}{l}\bullet \text { Inhibits } \\
\text { bone } \\
\text { formation } \\
\bullet \text { Allergic } \\
\text { reactions } \\
\bullet \text { Giant } \\
\text { cell } \\
\text { granu- } \\
\text { lomas } \\
\bullet \text { Nidus } \\
\text { for } \\
\text { infection } \\
\text { Inflamma } \\
\text { tion }\end{array}$ \\
\hline
\end{tabular}

Table 3. Bone Hemostasis Materials Comparison Chart.

$+{ }^{*}$ The prices are relative. The cost is estimated at price per application. Prices can vary based on institution and geographic location. The price ranges from $\$ 0-\$ 300.1$ - under $\$ 50 ; 2-\$ 50-\$ 100 ; 3-\$ 101$ $\$ 200 ; 4$ - Above $\$ 200$ 
four materials; one defect served as an empty control site. After two month healing, radiographic and histologic examination showed new bone formation in the presence of Avitene, Surgicel, and Gelfoam. Residual material incorporated in bone, without foreign-body response, was noted in the Avitene and Gelfoam sites. Bone wax, however, showed an intense foreign-body reaction, characterized by giant cells, plasma cells, fibrous granulation tissue, and lack of bone reformation. On the basis of these initial findings, it was concluded that Surgicel, Avitene, and Gelfoam might be adequate hemostatic agents for use in iliac bone procurement, whereas the use of bone wax appears to be contraindicated (Finn et al, 1992). 61

In 2010, Sawan and colleagues compared the effect of bone wax and a water-soluble alkylene oxide copolymer (AOC) material on mandibular bone healing in a rabbit model. Sawan's comparative study of 45 rabits was designed to assess the role of bone wax and the effectiveness of a new synthetic alternative bone hemostat in the context of oral and maxillofacial surgery. The animals were divided into three groups: bone wax and polymer groups and a hemostat-free group, which served as a control. A surgical bone defect was created in the anterior mandibular area. Alkylene oxide copolymer (AOC) hemostat-treated defects showed faster healing rate at the end of the first and second weeks than defects left untreated. The copolymer (AOC) disappeared from the surgical defect by the end of week one without any presence of inflammatory cells in the defect. In the bone wax group, the defects showed large empty vacuoles, representing bone wax remnants with inflammatory cells infiltration that interfered with bone healing. Study results showed that water soluble alkylene copolymer is a biodegradable material and that it does not interfere with bone healing. In contrast, bone wax proved to cause foreign body reaction, inhibiting bone healing (Sawan et al., 2010).

Two studies of topical bone hemostats conducted by Wellisz and colleagues in 2006 and 2008 compared the effect of non-resorbable traditional bone wax and water-soluble alkylene oxide copolymer (AOC) on sternal bone healing and cranial bone healing respectively in an animal model. After six weeks, the results of the sternal healing study involving 20 rabbits showed normal bone healing in the polymer-treated group and nonunion with fibrotic scar tissue and the absence of new bone formation in the bone wax group. While the bone hemostasis was immediate and comparable for both materials, the application of the polymer hemostatic material to the sternum resulted in significantly stronger union compared with the use of bone wax. Comparative cranial bone healing by Wellisz and colleagues assessing bone healing with bone wax and AOC in a group of 24 rabbits produced similar results (Wellisz et al., 2006, 2008a).

In a recent study, Armstrong and colleagues compared the effect of a water-soluble alkylene oxide copolymer (AOC) to oxidized regenerated cellulose (ORC) and microfibrillar collagen (MFC) on early bone healing in a rabbit tibia model with 12 animals. A group with no hemostatic material at all served as the control. Hemostasis was immediate after application of MFC and AOC, after 1-2 minutes with ORC, and $>5$ minutes for control. At 17 days postsurgery, micro-CT analysis showed near-complete healing in control and AOC groups, partial healing in the ORC group, and minimal healing in the MFC group. Fractional bone

${ }^{61}$ Finn, M. D., S. R. Schow, et al. "Osseous regeneration in the presence of four common hemostatic agents." J Oral Maxillofac Surg, 1992; 50(6): 608-612. 
volume was 8 fold greater in the control and AOC groups than in the MFC group and over 1.5-fold greater than in the ORC group. MFC remained at the application site with minimal healing at the defect margins and early fibrotic tissue within the defect. ORC-treated defects showed partial healing but with early fibrotic tissue in the marrow space. Conversely, control and AOC treated defects demonstrated newly formed woven bone rich in cellular activity with no evidence of AOC remaining at the application site. Armstrong and colleagues concluded that early healing appeared to be impaired by the presence of MFC and impeded by the presence of ORC. In contrast, AOC did not inhibit bone healing and may be a better bone hemostatic material for procedures where bony fusion is critical and immediate bone hemostasis required (Armstrong et al., 2010).

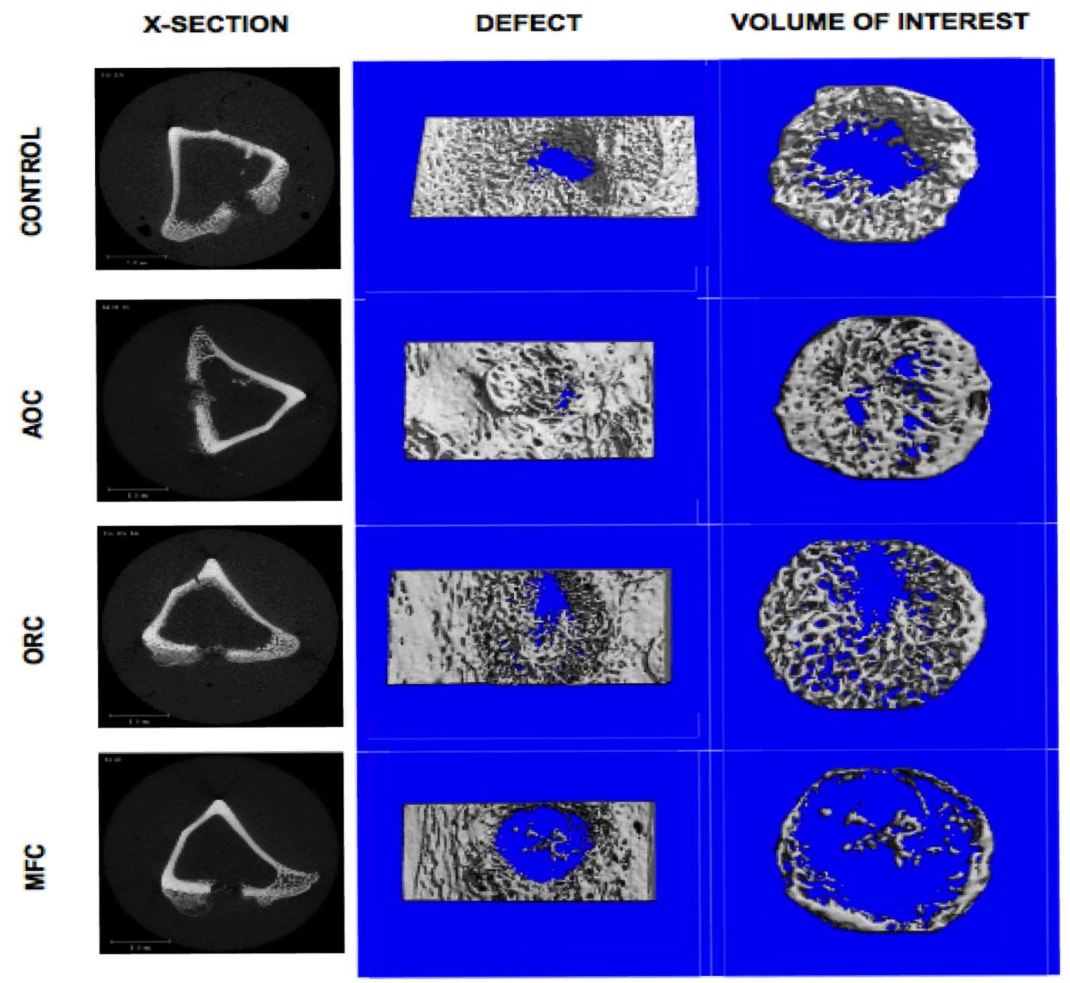

Fig. 2. Representative micro-CT images of excised rabbit tibiae at 17 days post-surgery. Left column: Cross-section views through the center of the defect showing newly formed bone as slightly opaque in untreated (control), alkylene oxide copolymer- and oxidized regenerated cellulose-treated defects, and an absence of opacity in microfibrillar collagen-treated defects (bar $=5.0 \mathrm{~mm}$ ). Center and right columns: micro-CT generated binarized images of mineralized tissue of the defect area (center) and area analyzed within the defect (right). AOC-treated and untreated (control) defects show substantial, well developed mineralized tissue, ORC-treated defect shows a more diffuse structure of mineralized tissue, and minimal mineralized tissue is observed within the MFC-treated defect. (Armstrong et al., 2010) 


\subsubsection{Studies of osteomyelitis with topical bone hemostats}

A 2008 comparative study assessing infection rates and healing in bone wax and AOC polymer treated bones with no treatment group as a control was designed to compare the two materials in a contaminated environment in a rabbit tibia defect model involving 24 animals. Bone defects were treated with the two topical bone hemostasis materials and then subject to a bacterial challenge by inoculation with Staphylococcus aureus. After 4 weeks, $100 \%$ of defects in the bone wax group became infected and developed osteomyelitis; none had evidence of bone healing. In the AOC polymer group and control group, $25 \%$ of defects developed osteomyelitis. The remaining $75 \%$ of defects in the polymer and control groups cleared the bacteria, showed no signs of osteomyelitis, and exhibited normal bone healing. The polymer-treated defects had a considerably lower rate of post-operative osteomyelitis and positive bone cultures compared with the bone wax-treated group. Wellisz and colleagues determined that there were no differences between the AOC polymer-treated group and control group in the rates of osteomyelitis, positive cultures, or bone healing, concluding that AOC may be a good alternative to bone wax when the risk of infection and bone healing are a concern (Wellisz et al., 2008b).

\subsubsection{Studies of effective bleeding management with topical bone hemostats}

In 2005, Block assessed the clinical effectiveness of several approaches to bone bleeding management in the context of complex spinal reconstructive procedures associated with excessive blood loss - the perioperative hemorrhage may be equivalent to estimated total blood volume, which significantly increases the risk of severe post-operative complications. Since highly vascular and widely exposed bony surfaces are not amenable to standard hemostatic maneuvers effective during soft tissue surgery, Block hypothesizes that underappreciated topical hemostatic agents may provide benefit by reducing the need for autologous predonation, banked donor blood, or antifibrinolytic agents. Topical agents Block evaluated -- combining collagen, thrombin and fibrin -- have demonstrated initial promise by inducing platelet aggregation and initiating the clotting cascade when applied directly to bleeding bony sites. Block's conclusion: clinical studies are clearly warranted (Block, 2005).

\section{Redefining the management of bone bleeding: osteomyelitis, bone healing, and topical therapeutics}

More clinical studies evaluating the merits of next generation bone hemostasis materials their handling, biocompatibility, safety, and effectiveness - are indeed warranted. Further research of the effectiveness of a wide range of existing alternatives to bone wax would help surgeons assess the properties and best use of all the available bone hemostasis options. It would open the way to using the management of bone bleeding as a tool to control blood loss and, at the same time, reduce the risk of post-operative infection, both of the soft tissue and osteomyelitis.

\subsection{Management of bone bleeding and topical therapeutics}

Topical use of anti-microbial agents applied to the cut sternum or vertebrae during surgery already shows promise in helping lower the incidence of post-operative osteomyelitis and soft tissue infection (Eklund, 2005; Friberg, 2005; Rohde, 1999). 
Some of the newly available synthetic materials designed to control bone bleeding in surgery may be able to expand the repertoire of choices available to surgeons during various surgical procedures without increasing risk to patients. Topical bone hemostasis agents in particular have the potential to redefine the management of bone bleeding and reduce the risk of post-operative complications, including osteomyelitis, by combining the application of bone hemostats with the delivery of therapeutics directly to the cut bone.

\subsection{Osteomyelitis prevention and topical bone hemostasis with antibiotics}

A soluble bone hemostasis material that is easy to handle, stops bleeding by mechanical occlusion, and does not inhibit osteogenesis or increase the risk of infection, may be mixed with antibiotics and used for local prophylaxis during and immediately after surgery. Such a formulation would retain the carrier's hemostatic properties to help manage bone bleeding and also allow for a controlled release of antibiotic of choice into the wound to prevent postoperative infection of the bone (osteomyelitis) or the surrounding tissue. The compound could be used during any surgical procedure - orthopedic, maxillofacial, neurological, or cardiac -- that involves the cutting of bone. If the existing studies of local antibiotic prophylaxis are any guide, antimicrobial bone hemostats used as an adjunct to systemic infection-preventing measures could reduce the risk of osteomyelitis at least by half.

\subsection{Bone healing and topical bone hemostasis with bone growth factors}

An analogous formulation combining bone hemostatic properties with bone growth factors could be used to deliver bone graft material to resected bone, whether in spinal fusion, repair of infected arthroplasty, or in the course of major reconstructive procedure following sternal wound debridement and removal of foreign materials during the treatment of deep mediastinitis. Bone graft delivered to the surgical site with topical bone hemostasis material as a carrier would be both osteoinductive and hemostatic, osteoconductive and easily moldable. Management of bone bleeding which incorporates bone hemostasis into the larger surgical procedure could simplify the operation, help reduce risk, and improve clinical outcome.

\section{Conclusion}

The choice of bone hemostasis material is a modifiable but widely overlooked postoperative infection risk factor, and proper management of bone bleeding may help reduce that risk. As a foreign body introduced during surgery into the wound, the bone hemostasis material can become a nidus of a surgical site infection. Traditional bone wax, in particular, illustrates this point. Despite its good handling and proven effectiveness, it inhibits bone healing and increases the risk of osteomyelitis across surgical procedures. Although great advances have been made in the use of antibiotic prophylaxis to reduce surgical wound complications, a better understanding of the impact of bone hemostasis technique and material choice on healing may help reduce infections and the rate of osteomyelitis even further, improving clinical outcomes. The possibility of combining topical bone hemostasis materials with therapeutics, such as antibiotics or bone grafts, may in the future broaden the repertoire of medical tools available to surgeons and redefine the role the management of bone bleeding could play in the prevention and treatment of osteomyelitis. 


\section{Acknowledgments}

The author would like to thank Anna Chodakiewicz and Kimberly Nolan for their invaluable assistance in preparing this manuscript.

\section{References}

AAOS Medical Letter: "Antibiotic Prophylaxis for Bacteremia in Patients with Joint Replacements." February 2009, Revised June 2010. http://www.aaos.org/about/papers/advistmt/1033.asp

Allison RT. Foreign body reactions and an associated histological artifact due to bone wax. Br. J. Biomed. Sci. 1994;51: 14-17.

Anfinsen, O. G., B. Sudmann, et al. (1993). "Complications secondary to the use of standard bone wax in seven patients." J Foot Ankle Surg 32(5): 505-508.

Armstrong et al. "The effect of three hemostatic agents on early bone healing in an animal model." BMC Surgery 2010, 10:37 http://www.biomedcentral.com/1471$2482 / 10 / 37$

Block JE.Severe blood loss during spinal reconstructive procedures: the potential usefulness of topical hemostatic agents. Med Hypotheses. 2005; 65(3):617-21

Brightmore T. G., P. Hayes, et al. (1975). "Haemostasis and healing following median sternotomy." Langenbecks Arch Chir Suppl: 39-41

Carmeli Y, Troillet N, Karchmer AW, et al. Health and economic outcomes of antibiotic resistance in Pseudomonas aeruginosa. Arch Intern Med. 1999;159:1127-1132

Centers for Disease Control and Prevention (CDC). Prevent antimicrobial resistance in healthcare settings.

http://www.cdc.gov/drugresistance/healthcare/problem.htm. Accessed September 27, 2009.

Centers for Disease Control and Prevention (CDC). National Center for Health Statistics. Leading causes of Death. http://www.cdc.gov/nchs/fastats/lcod.htm. Accessed July 30, 2011

Chun PKC, Virmani R, Mason TE, Johnson F. Bone wax granuloma causing saphenous vein thrombosis. Am. Heart J. 1988; 115:1310-1313.

Copenhaver WM, Kelly DE, Wood RL: The connective tissues: cartilage and bone, in Copenhaver WM, Kelly DE, Wood RL (eds): Bailey's Textbook of Histology, ed 17. Baltimore: Williams \& Wilkins, 1978, pp 170-205

Cosgrove SE et al. Health and economic outcomes of the emergence of third-generation cephalosporin resistance in Enterobacter species. Arch Intern Med. 2002. 162: 185-190

Edwards et al. The STS Practice Guideline Series: Antibiotic Prophylaxis in Cardiac Surgery, Part I: Duration. Annals of Thoracic Surgery 81(1): 397-404 (2006); Engelman R et al. The STS Practice Guideline Series: Antibiotic Prophylaxis in Cardiac Surgery, Part II: Antibiotic Choice. Annals of Thoracic Surgery 2007; 83: 1569-1576

Finn MD, Schow SR, Scneiderman ED. Osseous regeneration in the presence of four common hemostatic agents. J. Oral Maxillofac. Surg. 1992;50:608-612.

Friberg O, Svedjeholm R, Soderquist B, Granfeldt H, Vikerfors T, Kallman J. Local gentamicin reduces sternal wound infections after cardiac surgery: a randomized controlled trial. Ann Thorac Surg. 2005;79(1):153-61 
Geary JR, Kneeland Frantz V. New absorbable hemostatic bone wax; experimental and clinical studies. Ann Surg 1950;132:1128-37.

Georgia Epidemiology Report (GER). Community-associated Methicillin Resistant Staphylococcus aureus (MRSA). June 2004; 20:1-4.

Giannoudis, P.V., H. Dinopoulos, and E. Tsiridis, Bone substitutes: an update. Injury, 2005. 36 Suppl 3: p. S20-7

Gibbs L, Kakis A, Weinstein P, et al. Bone wax as a risk factor for surgical-site infection following neurospinal surgery. Infect Control Hosp Epidemiol 2004; 25:346Y348

Griffin XL, Smith CM, Costa ML. The clinical use of platelet-rich plasma in the promotion of bone healing: a systematic review. Injury 2009;40:158-62.

Hladki, W., L. Brongel, and J. Lorkowski, [Injuries in the elderly patients]. Przegl Lek, 2006. 63 Suppl 5: p. 1-4.0

Horsley V. Antiseptic wax. Br. Med. J. 1892; 1:1165 (letter)

Howard TC, Kelley RR. The effect of bone wax on the healing of experimental rat tibial lesions. Clin Orthop Relat Res 1969; 63:226 -32.

Ibarrola JL, Bjorenson JE, Austin BP, Gerstein H. Osseous reactions to three hemostatic agents. J Endod 1985;11:75-83.Johnson P, Fromm D. Effects of bone wax on bacterial clearance. Surgery 1981; 89:206-209.

Kalfas, IH., MD. Principles of Bone Healing. Neurosurg Focus 2001; 10 (4):Article 1, p. 7-10 From: http://pathwiki.pbworks.com/w/page/14673867/Bone23-27 (Accessed $7 / 31 / 2011)$

Kanafani ZA, Dakdouki GK, El-Dbouni O, Bawwab T, Kanj SS. Surgical site infections following spinal surgery at a tertiary care center in Lebanon: incidence, microbiology, and risk factors. Scand J Infect Dis. 2006;38(8):589-592.

Kreter B, Woods M. Antibiotic prophylaxis for cardiothoracic operations. Meta-analysis of thirty years of clinical trials. J Thorac Cardiovasc Surg 1992;104(3):590-9

Kronemyer B. MRSA incidence on the rise. Infectious Disease News. May 1, 2004. http://www.infectiousdiseasenews.com/article/33489.aspx. Accessed August 5, 2011

Lamm P., Gödje O.L., Lange T., Reichart B. Reduction of wound healing problems after median sternotomy by use of retention sutures. Ann Thorac Surg 1998; 66:21252126

Losanoff, J.E., Richman, B.W., Jones, J.W., Disruption and infection of median sternotomy: a comprehensive review Eur J Cardiothorac Surg 2002;21:831-839

Mary AM Rogers, Neil Blumberg, Sanjay Saint, Kenneth M Langa and Brahmajee K Nallamothu. Hospital variation in transfusion and infection after cardiac surgery: a cohort study. BMC Medicine 2009, 7:37doi:10.1186/1741-7015-7-37

Mclelland, S., Postoperative intracranial neurosurgery infection rates in North America versus Europe: A systematic analysis. Am J Infect Control 2008; 36:570-3Nelson DR, Buxton TB, Luu QN, Rissing JP. The promotional effect of bone wax on experimental Staphylococcus Aureus osteomyelitis. J. Thorac. Cardiovasc. Surg. 1990; 99:977-980.

Milano, A. Carmelo MD; Karen Kesler, MS; Nancy Archibald, MHA, MBA; Daniel J. Sexton, MD; Robert H. Jones,

MD Mediastinitis After Coronary Artery Bypass Graft Surgery.Circulation. 1995;92:2245 2251 doi:10.1161/01.CIR.92.8.2245 
National Hospital Discharge Survey: 2007 Summary, table 8. Centers for Disease Control and Prevention

http://www.cdc.gov/nchs/fastats/insurg.htm accessed July 31, 2011.

Nelson DR, Buxton TB, Luu QN, Rissing JP. The promotional effect of bone wax on experimental Staphylococcus aureus osteomyelitis. J Thorac Cardiovasc Surg 1990;99:977-80.

Neumayer, L., Vargo, D. (2008) Principles of Preoperative and Operative Surgery, In: Townsend: Sabiston Textbook of Surgery, 18th ed. Courtney M. Townsend Jr. R. Daniel Beauchamp B. Mark Evers, Kenneth L. Mattox, pp. (251-279), Saunders Elsevier, 978-1-4160-3675-3, Philadelphia, PA Rohde et al., "Spondylodiscitis after lumbar discectomy. Incidence and a proposal for prophylaxis." Spine (Phila Pa 1976), 1998 Mar 1;23 (5):615-20.

Nishida H, Grooters RK, Soltanzadeh H, Thieman KC, Schneider RF, Kim WP. Discriminate use of electrocautery on the median sternotomy incision. A $0.16 \%$ wound infection rate. J Thorac Cardiovasc Surg 1991;101:488-94.

Noskin G.A., Robert J. Rubin, et al. "The Burden of Staphylococcus aureus Infections on Hospitals in the United States." Arch Intern. Med. 2005;165:1756-1761.

Parker, R. (1892). "Aural pyaemia siccessfully treated by removing putrid thrombus of jugular vein and lateral sinus." The British Medical Journal 1: 1076-1077

Pairolero PC \& Arnold PG. Management of Infected Median Sternotomy Wounds Ann Thorac Surg, 1986; 42:1-2. DOI: 10.1016/S0003-4975(10)61822-X

Recker RR: Embryology, anatomy, and microstructure of bone, in Coe FL, Favus MJ (eds): Disorders of Bone and Mineral Metabolism. New York: Raven, 1992, pp 219-240.

Rogers MA, Blumberg N, Saint S, Langa KM, Nallamothu BK. Hospital variation in transfusion and infection after cardiac surgery: a cohort study. BMC Med 2009;7:37.

Sawan A, Elhawary Y, Zaghlool Amer M, \& Abdel Rahman M. “Controversial Role of Two Different Local Haemostatic Agents on Bone Healing." Journal of American Science, 2010; 6(12):155-163]. (ISSN: 1545-1003).

Schonauer C, Tessitore E, Barbagallo G, Albanese V, Moraci A. The use of local agents: bone wax, gelatin, collagen, oxidized cellulose. Eur Spine J. 2004;13 (suppl 1):S89_ S96.Shearwood McClelland III, Postoperative intracranial neurosurgery infection rates in North America versus Europe: A systematic analysis. Am J Infect Control 2008; 36:570-3

Solheim E, Pinholt EM, Bang G, Sudmann E. Effect of local hemostatics on bone induction in rats: a comparative study of bone wax, fibrin-collagen paste, and bioerodible polyorthoester with and without gentamicin. J Biomed Mater Res. 1992 Jun;26(6):791-800.

Sorrenti SJ, Cumming WJ, Miller D. Reaction of the human tibia to bone wax. Clin Orthop Relat Res 1984:293- 6.

Samudrala, S.. "Topical Hemostatic Agents in Surgery: A Surgeon's Perspective." AORN Journal, 2008. Supplement: Intraoperative Bleeding and Hemostasis in Surgical Procedures. vol. 88, no 3: p. S2-11

Styers D, Sheehan DJ, Hogan P, et al. Laboratory-based surveillance of current antimicrobial resistance patterns and trends among Staphylococcus aureus: 2005 status in the United States. Ann Clin Microbiol Antimicrob. 2006. 5:2 
Sudmann B, Bang G, Sudmann E. Histologically verified bone wax (beeswax) granuloma after median sternotomy in 17 of 18 autopsy cases. Pathology 2006; 38:138-41.

Szerafin Tamás, MD, Osama Jaber, MD, Árpád Péterffy, MD, PhD. Reduction of wound healing problems after median sternotomy (letter to the editor). Ann Thorac Surg 1999; 68: 2388.

Tang GH, Maganti M, Weisel RD, Borger MA. Prevention and management of deep sternal wound infection. Semin Thorac Cardiovasc Surg 2004;16:62-9.

Tomizawa Y. Clinical benefits and risk analysis of topical hemostats: a review. J Artif Organs 2005;8:137-42.

Eklund A.M. , M. Valtonen, K.A. Werkkala: Prophylaxis of sternal wound infections with gentamicin-collagen implant: randomized controlled study in cardiac surgery. Journal of Hospital Infection (2005) 59, 108-112.

Vander Salm TJ, Okike ON, Pasque MK, Pezzella AT, Lew R, Traina V, Mathieu R. Reduction of sternal infection by application of topical vancomycin. J Thorac Cardiovasc Surg 1989;98(4):618-22.

Verrall, P. J. (1924). Operation on Joints. Modern Operative Surgery. H. W. Carson. London, Cassell \& Co. 1: 69.

Watters WC III, MD et al. North American Spine Society Evidence-Based Clinical Guidelines for Multidisciplinary Spine Care, 2007.

Wellisz T, Armstrong JK, Cambridge J, Fisher TC: Ostene, a new water-soluble bone hemostasis agent. J Craniofac Surg 17: 420-425, 2006.

Wellisz T, An YH, Wen X, Kang Q, Hill CM, Armstrong JK. Infection rates and healing using bone wax and a soluble polymer material. Clin Orthop Relat Res 2008; 466:481-6.

Wellisz T, Armstrong JK, Cambridge J, et al. The effects of a soluble polymer and bone wax on sternal healing in an animal model. Ann Thorac Surg 2008; 85:1776-80. 


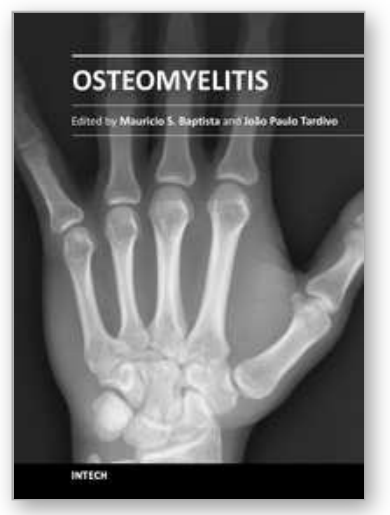

\author{
Osteomyelitis \\ Edited by Prof. Mauricio S. Baptista
}

ISBN 978-953-51-0399-8

Hard cover, 180 pages

Publisher InTech

Published online 23, March, 2012

Published in print edition March, 2012

If you want to learn more about osteomyelitis you should not miss this book. The editors are professionals and scientists working in health sciences and the chapters have been prepared by experts in the field, covering subjects related with the fundamentals of osteomyelitis and new diagnosis and treatment tools. You will have the opportunity to review concepts as well as to learn state-of-the-art alternatives for diagnosis and treatments.

\title{
How to reference
}

In order to correctly reference this scholarly work, feel free to copy and paste the following:

Tadeusz Wellisz (2012). Management of Bone Bleeding During Surgery and Its Impact on the Incidence of Post-Operative Osteomyelitis, Osteomyelitis, Prof. Mauricio S. Baptista (Ed.), ISBN: 978-953-51-0399-8, InTech, Available from: http://www.intechopen.com/books/osteomyelitis/management-of-bone-bleeding-duringsurgery-and-its-impact-on-the-incidence-of-post-operative-osteomy

\section{INTECH}

open science | open minds

\author{
InTech Europe \\ University Campus STeP Ri \\ Slavka Krautzeka 83/A \\ 51000 Rijeka, Croatia \\ Phone: +385 (51) 770447 \\ Fax: +385 (51) 686166 \\ www.intechopen.com
}

\author{
InTech China \\ Unit 405, Office Block, Hotel Equatorial Shanghai \\ No.65, Yan An Road (West), Shanghai, 200040, China \\ 中国上海市延安西路65号上海国际贵都大饭店办公楼405单元 \\ Phone: +86-21-62489820 \\ Fax: $+86-21-62489821$
}


(C) 2012 The Author(s). Licensee IntechOpen. This is an open access article distributed under the terms of the Creative Commons Attribution 3.0 License, which permits unrestricted use, distribution, and reproduction in any medium, provided the original work is properly cited. 